Põlluste, K., Kasiulevicius, V., Veide, S., Kringos, D.S., Boerma, W., Lember, M. Primary care in Baltic countries: a comparison of progress and present systems. Health Policy: 2013, 109(2) $122-130$

\begin{tabular}{|l|l|}
\hline $\begin{array}{l}\text { Postprint } \\
\text { Version }\end{array}$ & 1.0 \\
\hline Journal website & $\underline{\text { http://www.healthpolicyirnl.com/article/S0168-8510(12)00224-2/abstract }}$ \\
\hline Pubmed link & $\underline{\text { http://www.ncbi.nlm.nih.gov/pubmed/22964369 }}$ \\
\hline DOI & 10.1016/j.healthpol.2012.08.015 \\
\hline
\end{tabular}

This is a NIVEL certified Post Print, more info at http://www.nivel.eu

\title{
Primary care in Baltic countries: A comparison of progress and present systems
}

\author{
Kaja Polluste ${ }^{A, *}$, Vytautas KasiuleVi ${ }^{\circ}$ CIUS $^{\mathrm{B}}$, SaRmite Veide ${ }^{\mathrm{C}}$, DionNe Sofia \\ KRINGOS $^{\mathrm{D}, \mathrm{E}}$, WIENKE BOERMA ${ }^{\mathrm{D}}$, MARGUS LEMBER ${ }^{\mathrm{A}}$
}

a University of Tartu, Department of Internal Medicine, L. Puusepa 6, Tartu 51014, Estonia b Vilnius University, Faculty of Medicine, Santariskiu 2, LT-08661, Vilnius, Lithuania c Latvian Family Physicians' Association, $\mathrm{Br}^{-} \mathrm{IV}{ }^{-}$Ibas iela 58, 516. telpa, $\mathrm{R}^{-}$Iga, LV1011, Latvia

d NIVEL - Netherlands Institute for Health Services Research, PO Box 1568, 3500 BN Utrecht, The Netherlands

e Academic Medical Center, University of Amsterdam, Department of Social Medicine, Meibergdreef 9, 1105 AZ Amsterdam, The Netherlands

\begin{abstract}
Objectives: This study aims to compare the organisation of primary care (PC) systems in Estonia, Latvia and Lithuania, focusing on the structure and process of service delivery, and to discuss the suitability of the PHAMEU instrument for international comparison of PC systems.

Methods: The data were collected in the framework of PHAMEU project during 2009-2010.

The selected indicators were used to describe and compare the structure and process of PC in Estonia, Latvia and Lithuania.

Results: The results showed that the coordination of PC services, legislative framework, service delivery, quality requirements and PC financing principles are rather similar in all three Baltic countries. Population coverage for PC services, cost sharing for some services, and the employment status of family doctors differs by country. The PHAMEU instrument was most applicable for the description and comparison of the structure of PC and some aspects of the process. Information about patient outcome and quality of care was neither available nor reliable enough.

Conclusion: The development of PC systems in Baltic countries has been rather similar, but some aspects also differ between the countries. Use of a
\end{abstract}


Põlluste, K., Kasiulevicius, V., Veide, S., Kringos, D.S., Boerma, W., Lember, M. Primary care in Baltic countries: a comparison of progress and present systems. Health Policy: 2013, 109(2) 122-130

standardized instrument allows for international comparison, but assumes standardised data collection procedures in comparable countries.

\section{INTRODUCTION}

In the late 1980s and early 1990s, Estonia, Latvia and Lithuania, like all of the Central and Eastern European (CEE) countries, experienced great changes in their political and economic systems, which also led to reforms in national health systems. Since WWII, all Baltic countries have been part of the Soviet Semashko-type health care. After regaining independence in 1991, these countries introduced health care reforms of their own. This resulted in a considerable change of health care resources and utilisation, amongst other changes. This is illustrated by a selection of indicators of health care resources and utilisation in Baltic countries in the 1990s and 2009 in Table $1[1]$.

\section{[TABLE 1]}

A reform process is concerned with defining priorities, refining policies, and reforming institutions through which those policies are implemented [2]. Thus, a health reform must look toward changes in policy objectives followed by institutional change - it must be purposive and sustain the long-term process and should be led as a political process by the government [3]. A health reform could be comprehensive, but it can be focused also on one part of the health system. A previous study indicated that health policies in all Baltic countries have been progressing in parallel towards a Western European social insurance funding model, developing a primary care (PC) system anchored on general practitioner service and lessening the hospital orientation of the pre-1990s system [4].

Although the health reforms in all Baltic countries have been comprehensive, the introduction of a new health care system based on family medicine (FM) was recognised as a priority of health care policymakers and has received strong support from the government [5]. The implementation of a new PC system in all Baltic countries included the main components of health reform as defined by Cassels [2]: (1) training of staff by establishing a postgraduate training program for FM as well as retraining of doctors [4-9]; (2) changing the financing and remuneration system of family doctors (FDs) [8-10] to motivate PC doctors as well as implementation of the gate-keeping function of FDs and creating the patient lists [4,8-12]; (3) separating PC and secondary care services; (4) increasing the responsibilities of the PC system; and (5) changing the whole funding system of health care. The key characteristics of PC reforms in Baltic countries are presented in Table 2.

The progress of PC reform in Baltic countries has been examined in several studies. There are a number of studies about the Estonian PC system, explaining access to PC services [13], patient satisfaction and acceptability of the PC system [11,14] as well as economic aspects of PC reform $[15,16]$. The studies about PC reforms in Latvia and Lithuania primarily focus on patient satisfaction and acceptability of the PC system [17-20].

During the last 20 years many countries have attempted to reform their PC systems, each with different implementation processes for PC reform. However, only a few rigorous assessments have been done of the implemented PC reforms and resulting PC system [21]. There is currently a lack of up-to-date comprehensive and 
Põlluste, K., Kasiulevicius, V., Veide, S., Kringos, D.S., Boerma, W., Lember, M. Primary care in Baltic countries: a comparison of progress and present systems. Health Policy: 2013, 109(2) 122-130

comparable information on variations in development of PC, and a lack of knowledge of structures and strategies conducive to strengthening PC in Europe. There is no agreement on how to assess the reforms comprehensively. Recently, a panel of experts developed a standardised instrument (Primary Care Monitor System) for describing and comparing PC systems within the framework of the EU-funded PHAMEU project for application in 31 European countries.

The instrument developed describes the key dimensions of PC systems both at the structural level (governance, economic conditions, and workforce development), and at the process level (access, comprehensiveness, continuity, and coordination of PC services) [22]. This provides an opportunity to evaluate PC in Baltic countries. This article therefore aims to compare the organisation of PC systems in Estonia, Latvia and Lithuania, focusing on their PC structure and process of service delivery, and to discuss the suitability of the PHAMEU instrument for international comparison of PC systems.

\section{Materials AND MEthods}

The data were collected within the framework of the PHAMEU (Primary Health Care Activity Monitor for Europe) project during 2009-2010 by the project participants from ten participating countries and according to the standardised instrument [22]. The PHAMEU project covered the 27 European Union member states, and Turkey, Iceland, Norway and Switzerland.

In this study, we used the selected indicators to describe and compare the structure and process of PC in Estonia, Latvia and Lithuania. To evaluate the structure we used the indicators of PC governance and selected indicators of economic conditions, whilst the process of service delivery was evaluated by selected indicators of PC access, continuity of care and some aspects of patient experiences. The indicators used in this study were defined according to the PHAMEU instrument [22] and presented in Table 3 . The selection of indicators was made based on the assumption of availability of reliable data to describe these indicators.

\section{[TABLE 2]}

The main data sources were: (1) administrative and routinely collected data (e.g., PC expenditure, PC coverage, availability of FDs, employment status and remuneration of FDs, cost sharing for FM care, home visits); and (2) results of previous studies, e.g., stability of the patient-practitioner relationship and patient satisfaction. The most recently available data were used. All data used in this study are derived from the dataset which resulted from the PHAMEU project [23].

\section{RESULTS}

\subsection{Governance of $P C$}

The indicators describing the governance of PC in Baltic countries are presented in Table 4. PC in Baltic countries is coordinated on the governmental level (by the Ministry of Social Affairs in Estonia and by the Ministries of Health in Latvia and Lithuania), whereas in Lithuania there is a special division of FM within the ministry and since 2011 in Latvia, too. In Latvia and in Estonia PC service delivery is organised at the national level; in Lithuania in some regions the local authorities own the PC facilities and service delivery is decentralised. 
Põlluste, K., Kasiulevicius, V., Veide, S., Kringos, D.S., Boerma, W., Lember, M. Primary care in Baltic countries: a comparison of progress and present systems. Health Policy: 2013, 109(2) 122-130

In all countries the organisation of PC and service delivery is regulated by several legislative acts; in Estonia and in Lithuania there are also policy documents which formulate the vision and goals of PC. Also, the multidisciplinary collaboration at PC level is laid down in policy papers or in legislative acts and the basic patient rights (e.g., informed consent, confidentiality, and complaints procedure) are defined by legislative acts. Equality in access is a clearly stated policy goal in Estonia and Latvia, where the distribution of PC providers is planned according to the size of population. In Lithuania, the policy on equality in access is not clearly defined. In all Baltic countries the organisations of stakeholders (e.g., organisations of medical professionals or patients) contribute to PC policy development; however, this is rather informal than formally regulated.

The quality requirements for PC are defined in all Baltic countries. There are formal requirements for FDs (completed residency training and certificate of FD) as well as for the premises and equipment. Recertification for FDs is obligatory in Latvia and Lithuania, but voluntary in Estonia.

The clinical guidelines for FDs are produced in all countries, mainly by associations of FDs in collaboration with other medical specialists. Patient satisfaction is surveyed in all countries as well.

\subsection{Economic conditions for $P C$}

The total expenditure on PC as a percentage of total health care expenditure depends on the definition of PC services. According to Eurostat [24] the percentage of expenditure on ambulatory care (including PC and specialist services) of total expenditure on health were 21.0\% in Estonia (2008), 26.7\% in Latvia (2006) and 22.8\% in Lithuania (2008). The expenditures on PC services in 2009 in Estonia were 7.1\%, in Latvia 9.7\% and in Lithuania 13.8\%. In Estonia, PC expenditures include only the expenditures related to the provision of FD services, in Latvia PC expenditures also include dentistry for children, and in Lithuania PC expenditures include dentistry for children and adults.

\section{[TABLE 3]}

Coverage of FD services in 2009 in Estonia was 95.6\%, in Latvia 100\%, and in Lithuania 95\%.

In 2009, the average gross income per practice per month in Estonia was D 6930, in Latvia D 3568 (in January-June 2010) and in Lithuania D 5520. The average practice sizes were 1600, 1584 and 1550 registered patients, respectively. The numbers of FD contacts are presented in Table 1.

\subsection{Employment status of FDs}

In Estonia and Latvia, most FDs are self-employed contractors to the health insurance fund (HIF), and in Lithuania the majority of FDs are salaried with regional health authorities, whereby the national HIF is the financer of PC services. The employment status of FDs is presented in Fig. 1.

\subsection{Remuneration systems for FDs}

For the self-employed FDs, payment in all countries includes capitation, fixed components and additional components (Fig. 2). The fixed components for payment in Estonia include funding for lab tests and investigation and basic practice allowance, in Lithuania additional payment to FDs who are working in rural areas, 
Põlluste, K., Kasiulevicius, V., Veide, S., Kringos, D.S., Boerma, W., Lember, M. Primary care in Baltic countries: a comparison of progress and present systems. Health Policy: 2013, 109(2) 122-130

and in Latvia payment for patient density, distance to the hospital, maintenance of the practice and the FD certificate.

\section{[TABLE 4]}

Additional components of payment in Estonia include payment for performance indicators (e.g., care for chronically ill patients and immunisation of children) as well as for the distance to the hospital (for FDs who are working more than $20 \mathrm{~km}$ from the nearest hospital). In Latvia, FDs are paid additionally for some medical manipulations (for example, prevention, "minor" surgery, laboratory tests), for the salary of nurses or physician' s assistants and for medical care of patients who are not registered, as well as payment for performance indicators (coverage of prevention, immunisation and some indicators for care of chronically ill patients).

\section{[FIGURE 1] [FIGURE 2]}

The additional components in Lithuania include payment for performance indicators (e.g., low hospitalisation rate, child immunisation rate, and patient visits rate) as well as for participation in prevention and early diagnostic programmes (e.g., cervical and breast cancer, cardiovascular prevention, colorectal and prostate cancer).

Salaried FDs are mostly paid a flat salary in Estonia and salary related to the number of patients and/or indicators of performance in Latvia and Lithuania.

\subsection{Access to PC services}

The indicators of access to PC services are presented in Table 5. The number of FDs per 100,000 in population in 2008 varied from 58.4 in Latvia to 62.4 in Lithuania. In all Baltic countries the FD practices are obliged to have a minimum number of working hours. In Estonia, the FD practice should have at least eight working hours per day on working days (Monday-Friday) and in Latvia at least $40 \mathrm{~h}$ per week. In Lithuania, the number of working hours depends on municipality administration rules and varies between municipalities, but the minimum number is $6 \mathrm{~h}$ per day. However, the FD practices are mostly open $12 \mathrm{~h}$ per day.

The after-hours services in all countries are provided mostly by the hospital emergency departments and/or by ambulance service. In Estonia and Latvia the outof-hours service is not stipulated in the FD contract. In Lithuania, hospital emergency departments provide PC services from 6 p.m. to 7 a.m., but FDs have to pay the hospital for this care.

\section{[TABLE 5]}

The number of home visits in 2008 was highest in Lithuania and lowest in Estonia. In Latvia the average number of home visits includes FD visits to a patient' s home fully covered by the state only to children (until the age of 18) and some disadvantaged patient groups (e.g., persons over 80 years of age, disabled persons, or patients receiving home care or palliative care).

Satisfaction with access to PC in 2007 [25] was highest in Estonia and lowest in Latvia (Fig. 3).

\subsection{Affordability of PC services}

Table 5 presents the indicators of cost sharing for PC services. In Estonia, patients do not have to pay for the visit to the FD, but there is some co-payment for the 
Põlluste, K., Kasiulevicius, V., Veide, S., Kringos, D.S., Boerma, W., Lember, M. Primary care in Baltic countries: a comparison of progress and present systems. Health Policy: 2013, 109(2) $122-130$

medicines prescribed by the FD (the rate of co-payment depends on the diagnosis and medicines prescribed), for the visit to a specialist prescribed by the FD, as well as for the FD visit to the patient' s home. In both cases the co-payment could be up to 3.2 EUR per visit, except for children up to two years and pregnant women from the twelfth week of pregnancy.

\section{[FIGURE 3]}

In Latvia there is some co-payment for FD visits, as well as visits to specialists. There are some patient groups who do not have co-payment, as their care is covered by the state, e.g. children until the age of 18, pregnant women, the disabled and those whose income is less than one-half of the minimum wage. Also, in case of preventive visits the patient has no co-payment. Home visits are fully paid by the patient, with the exception of the aforementioned patient groups. There is also a ceiling for copayments - a maximum of D 570 per year. As in Estonia, there is also a co-payment for prescribed medicine depending on the diagnosis. However, for persons with a low income there is a ceiling for co-payments for prescribed medicines, too. In Lithuania the patients do not have to pay for visits to the FD or specialists, or for home visits. Still, there is some co-payment for prescribed medicines, which similarly to Estonia and Latvia depends on the diagnosis.

According to the Eurobarometer survey in 2007 [25], patient dissatisfaction with prices was highest in Lithuania and lowest in Latvia, but it was low overall in all countries (Fig. 3).

\subsection{Continuity of care}

In all three Baltic countries the FDs have a patient list system and the patients are free to choose the FD with whom they want to register (Table 5). Nevertheless, this choice is in reality limited in areas where the population density is low and there is only one FD for the region.

\section{DISCUSSION}

\subsection{Comparison of PC systems in Estonia, Latvia and Lithuania}

Previously, the most comprehensive analysis of the PC system was done in Estonia, but by using the standardised instrument in this study we compared the organisation of PC systems in all three Baltic countries. Reasons for the reorganisation of health systems in the beginning of 1990s were similar in all three countries, and the introduction of FM-based PC was one of the priorities in Estonia, Latvia and Lithuania [4,5]. Also, the principles of implementation for the new PC system were similar [4,5,7-12]. When analysing the progress of PC reforms in Baltic countries, we found that all countries have followed more or less the basic elements of health reform [2]. Although the objectives were not very clearly defined in the beginning of the changes, the need for several reforms, as well as the content of the reforms, including the PC reform was shared by different parties.

Therefore, the necessary changes for the development of the new system started already before the formal definition of the objectives. For example, in Estonia the training of staff was initiated already in 1991; however, the objectives of reform were formulated and the first legislative acts to support the reform were laid down in 1997. 
Põlluste, K., Kasiulevicius, V., Veide, S., Kringos, D.S., Boerma, W., Lember, M. Primary care in Baltic countries: a comparison of progress and present systems. Health Policy: 2013, 109(2) 122-130

At present, all Baltic countries have implemented the PC strategy. This study showed a lot of similarities in the structure and process of PC in all countries, such as the coordination and organisation of PC, service delivery, and quality requirements. The payment systems in all three countries include capitation as the main source of financing and additional payments related to quality of care have been introduced in all Baltic countries. There are also a lot of similarities from the patients' point of view: all countries have introduced a patient list system and patients are free to choose their GP. The PC services during office hours are provided by FDs, and the out-of-hours services are provided mainly by hospitals and ambulance. Also, all countries have introduced some co-payment for prescribed medicines which depends on the diagnosis.

Still, there are also some differences. The vision and goals, as well as policy on equality in access, are more clearly defined in Estonia and Latvia than in Lithuania. Decentralisation of service delivery is more expressed in Lithuania, where the municipalities in some regions own the PC facilities and have set some additional rules for the facilities as well (e.g., the number of working hours of PC practices). The coverage of the population for FDs' services is somewhat different and depends on the financing principles of a country' s health system. The cost sharing for some PC services differs as well. For example, in Lithuania the home visits are free for all patients whilst in Estonia there is some co-payment and in Latvia the home visits are fully paid by the patient, with the exception of some patient groups. That might be one reason why the number of home visits differs by countries and is in Lithuania three to four times higher than in Latvia and Estonia.

The figures describing expenditures of PC services in Estonia, Latvia and Lithuania were different, too. The main reason for this difference is how the PC is defined and what is included. For example, in Estonia PC expenditures include only the FD and family nurse services; in Latvia and Lithuania, on the other hand, PC expenditures also include dental health services for children and adults. Thus, the comparison of PC expenditures is rather difficult.

Employment status of FDs is different as well. Whilst in Estonia and Latvia the great majority of FDs work as independent contractors with HIF, in Lithuania most of the FDs work as salaried doctors.

Satisfaction with access to the FD services was highest in Estonia and lowest in Latvia; at the same time dissatisfaction with prices in Lithuania was almost three times higher than in Estonia and Latvia. Satisfaction with access did not correspond to the availability of FDs. When comparing some indicators of access, such as cost sharing for FD care and dissatisfaction with prices the results are rather surprising dissatisfaction was highest in Lithuania, where patient co-payment for visits to the FD, specialist, or home visits does not exist. It has been argued previously that patient satisfaction is not dependent on the national health system [26], and this opinion seems to be confirmed by our results as well.

In general, against the reforms in former Soviet countries and Central and Eastern European countries [21], the Baltic countries seem to be rather successful in implementing the PC reforms. The legal framework for PC has been established, new principles of financing have been introduced, and the access to and satisfaction with PC services is rather good. However, there is some potential to improve access to PC services in the future, e.g., to ensure coverage with PC services to the entire population in Estonia and in Lithuania. Another field which has been discussed is the 
Põlluste, K., Kasiulevicius, V., Veide, S., Kringos, D.S., Boerma, W., Lember, M. Primary care in Baltic countries: a comparison of progress and present systems. Health Policy: 2013, 109(2) 122-130

delivery of after-hours care. At present, in all three countries after-hours care is provided by hospital emergency departments and ambulance services. This has resulted from a rather good hospital and ambulance services network, as well as rather low population density (mainly in rural areas). Still, it could be considered that the after-hours care might be partly provided within PC, too, such as in areas with high population density.

\subsection{Practical application of the PHAMEU instrument for comparison of $P C$ in Baltic countries}

In this study we used the selected indicators collected within the framework of the PHAMEU project during 2009-2010. The set of indicators proposed by the experts was rather comprehensive [22]. However, the data collection process taught us that several indicators (e.g., about comprehensiveness or quality) could only be completed by an expert opinion. Thus, the data set used in this study was limited. The most reliable data were those collected routinely by administrative purpose. Despite several data limitations, the best available and most data in 2009/2010 were used, and applied in this article [22].

This instrument is expected to provide insight into strong features that should be maintained and weaker spots to be strengthened in the future. In our study we found that the PHAMEU instrument was most applicable for the description and comparison of governance of PC.

The data to describe the indicators of governance were collected from several legislative acts and policy papers. Also, the definitions of indicators were very explicit.

When describing the economic conditions of PC we found the total expenditure of $\mathrm{PC}$ to be the most unclear indicator. It is clear that the total expenditure on PC as a percentage depends on the definition of PC services and could vary between the countries. When looking at the Eurostat statistics [24], we found the amount of expenditure on out-patient care which includes PC and specialist services.

These numbers were rather similar for all Baltic countries.

However, if we tried to calculate only the expenditures on PC services we found that the number differed by almost two times. At the same time, the definitions of PC expenditures are also different, as discussed above. On the other hand, data about payment options in PC and remuneration system of FDs were clearly defined and easily accessible for all Baltic countries, and therefore these aspects were more clearly described as well.

Data about some aspects of access to PC services (e.g., availability of PC services or working hours), affordability of PC services (cost sharing of FD care) and continuity of care (e.g., patient list system, and physician choice) were easily available. Still, a lot of information, such as that regarding the comprehensiveness of care, was based on the opinions of experts, and for that reason we did not find it to be reliable enough for this comparison.

Some problems occurred also by describing the patient's opinion. For example, in this paper we did not compare the stability of the patient- ${ }^{-}$provider relationship expressed by the percentage of patients reporting to visit their usual PC provider for their common health problems. This aspect of continuity of care is studied in Baltic countries in different way at different times and therefore these numbers may not be fully comparable. The same problem was related to patient satisfaction with the FD, 
Põlluste, K., Kasiulevicius, V., Veide, S., Kringos, D.S., Boerma, W., Lember, M. Primary care in Baltic countries: a comparison of progress and present systems. Health Policy: 2013, 109(2) $122-130$

where the data were also collected in different ways. Thus, we used only these aspects of satisfaction which were studied in the Eurobarometer study by using the uniform instrument [25].

One important aspect in every health system is related to the output or quality of care. The PHAMEU instrument also includes a number of quality indicators; however, information about these was neither available nor reliable.

\section{CONCLUSION}

This study has two outcomes. Firstly, it compares the PC systems in Estonia, Latvia and Lithuania using the standardised instrument. Secondly, this is the first study using the PHAMEU instrument. Therefore, this could be considered a first test of the instrument in a real comparison of the PC system in three Baltic countries.

At present, all three Baltic countries have reformed their PC systems. The legal framework for PC has been implemented, the financing systems developed, and the necessary number of staff trained. There are a lot of similarities in all countries, but on the other hand, some aspects such as the decentralisation of service delivery and financing principles also differ between the countries.

This comparison was performed using the PHAMEU instrument. Currently, the most applicable indicators were related to the structure - governance and financing where routinely collected, reliable data are available. Still, some indicators should be more clearly defined (e.g., total expenditure of PC costs). A lot of indicators describing the process and quality are based on survey data and require special data collection forms, which are not used in every country.

Therefore, for international comparison it would be useful to perform uniform surveys to gather the patient' s opinion.

To collect data about the quality of PC the countries should introduce special data collection forms.

\section{ACKNOWLEDGEMENTS}

The study is part of the PHAMEU (Primary Health Care Activity Monitor) project, co-funded by the European Commission, DG Health and Consumers.

\section{REFERENCES}

[1] World Health Organization., http://data.euro.who.int/hfadb/ [accessed 11.05.12].

[2] Cassels A. Health sector reform: key issues in less developed countries.

Geneva: WHO; 1995.

[3] Eriksson P, Lonnroth K, Karlberg I, Diwan V. Hospitals in reform - current trends. In: Eriksson P, Diwan V, Karlberg I, editors. Health sector reforms: what about hospitals? NHV report 2002:04. Goteborg: The Nordic School of Public Health; 2002.

[4] Bankauskaite V, O' Connor JS. Health policy in the Baltic countries since the beginning of the 1990s. Health Policy 2008;88:155-65.

[5] Svab I, Pavlic DR, Radic S, Vainiomaki P. General practice east of Eden: an overview of general practice in eastern, Europe. Croatian Medical Journal 2004;45:537-42.

[6] Lember M. Family practice training in Estonia. Family Medicine 1996;28:282-6.

[7] Maaroos HI. Family Medicine as a model of transition from academic medicine to academic health care: Estonia' s experience. Croatian Medical Journal 2004;45:563-6.

[8] Tragakes E, Brigis G, Karaskevica J, Rurane A, Stuburs A, Zusmane E, et al. Latvia: health system review. Health Systems in Transition 2008;10(2):1-253. 
Põlluste, K., Kasiulevicius, V., Veide, S., Kringos, D.S., Boerma, W., Lember, M. Primary care in Baltic countries: a comparison of progress and present systems. Health Policy: 2013, 109(2) $122-130$

[9] Health care systems in transition: Lithuania. European observatory on health care systems. Copenhagen: WHO Regional Office for Europe; 2000.

[10] Lember M. A policy of introducing a new contract and funding system of general practice in Estonia. International Journal of Health Planning and Management 2002;17:41-53.

[11] Polluste K, Kalda R, Lember M. Primary health care system in transition: patients' experience. International Journal for Quality in Health Care 2000;12:503-9.

[12] Kalda R, Polluste K, Lember M. Patient satisfaction with care is associated with personal choice of physician. Health Policy 2003;64:55-62.

[13] Kalda R, Polluste K, Maaroos HI, Lember M. Patients' opinion on family doctor accessibility in Estonia. Croatian Medical Journal 2004;45:578-81.

[14] Polluste K, Kalda R, Lember M. Evaluation of primary health care reform in Estonia from patients' perspective: acceptability and satisfaction.

Croatian Medical Journal 2004;45:582-7.

[15] Koppel A, Meiesaar K, Valtonen H, Metsa A, Lember M. Evaluation of primary health care reform in Estonia. Social Science and Medicine 2003;7:2461-6.

[16] Meiesaar K, Lember M. Efficiency and sustainability of using resources in Estonian primary health care. Croatian Medical Journal 2004;45:573-7.

[17] Attieksme un inform ${ }^{-}$et ${ }^{-}$Iba par vesel ${ }^{-}$Ibas apr ${ }^{-}$upes sist ${ }^{-}$emu Latvij ${ }^{-}$a.

Latvijas iedz ${ }^{-}$Ivot ${ }^{-}$aju aptauja. [Attitude to and knowledge about health care system in Latvia. Opinion survey of inhabitants of Latvia.] Baltijas Datu nams/Baltijas Soci- ${ }^{-}$alo Zin ${ }^{-}$atn, u instit - uts; 2000.

[18] Toma S, Executive MBA. Diploma project. What are the determinant factors in employee and patient satisfaction in the primary health care segment in Latvia? Stockholm School of Economics in Riga; 2010.

[19] Zebiene E, Razgauskas E, Basys V, Baubiniene A, Gurevicius R, Padaiga Z, et al. Meeting patient' $s$ expectations in primary care consultations in Lithuania. International Journal for Quality in Health Care 2004;16:83-9.

[20] Health Payment Center. $\mathrm{P}^{-}$et ${ }^{-}$ijums "ledz ${ }^{-}$Ivot ${ }^{-}$aju apmierin ${ }^{-}$at ${ }^{-}$iba ar vesel ${ }^{-}$ibas apr ${ }^{-}$upes pakalpojumiem un to san, em sanas iesp ${ }^{-}$ej $^{-}$am [Study "Residents' satisfaction with health care services and availability]; 2008. Website of Health Payment Center, http://www.vnc.gov.lv/eng/ [accessed 11.05.12].

[21] Rechel B, McKee M. Health reform in Central and Eastern Europe and the former Soviet Union. Lancet 2009;374:1186-95.

[22] Kringos DS, Boerma WGW, Bourgueil Y, Cartier T, Hasvold T, Hutchinson A, et al. The European primary care monitor: structure, process and outcome indicators. BMC Family Practice 2010;11:81-9.

[23] Kringos DS, Boerma WGW, Hutchinson A, editors. Building primary care in a changing Europe. European Observatory on Health Systems and Policies, forthcoming.

[24] Europe in figures. Eurostat Yearbook 2011. Available at: http://epp.

eurostat.ec.europa.eu/portal/page/portal/publications/eurostat yearbook 2011 [accessed 11.05.12].

[25] Health and long-term care in European Union. Special Eurobarometer 283. European Commission; 2007. Available from: http://ec.europa.eu/public opinion/archives/ebs/ebs 283 en.pdf [accessed 11.05.12].

[26] Wensing M, Baker R, Szecsenyi J, Grol R, EUROPEP Group. Impact of national health care systems on patient evaluations of general practice in Europe. Health Policy 2004;68:353-7. 
Põlluste, K., Kasiulevicius, V., Veide, S., Kringos, D.S., Boerma, W., Lember, M. Primary care in Baltic countries: a comparison of progress and present systems. Health Policy: 2013, 109(2) 122-130

\section{TABLES AND FIGURES}

Table 1

Health care resources and utilisation in Estonia, Latvia and Lithuania in the 1990s and 2009 .

\begin{tabular}{|c|c|c|c|c|c|c|}
\hline \multirow[t]{2}{*}{ Indicators } & \multicolumn{2}{|l|}{ Estonia } & \multicolumn{2}{|l|}{ Latvia } & \multicolumn{2}{|c|}{ Lithuania } \\
\hline & 1991 & 2009 & 1991 & 2009 & 1991 & 2009 \\
\hline Total health expenditure as $\mathcal{Q}$ of GDP & 5.90 & 7.0 & 26 & $6.0^{\circ}$ & 3.7 & 7.6 \\
\hline Total health expenditures per capita (in PPp \$) & $513^{2}$ & 1393 & 183.8 & $1209.4^{b}$ & 335.5 & 13102 \\
\hline Hospital beds (per 100,000 population) & 1128.9 & 5439 & 1343.0 & 640.1 & 1245.5 & 6803 \\
\hline Physicians (per 100,000 population) & 353.6 & 326.7 & 361.1 & 299.5 & $358.3^{\mathrm{E}}$ & 365.1 \\
\hline GP's as $\mathcal{Q}$ of all physicians & 0 & 25.1 & 0 & 19.5 & 0 & 18.9 \\
\hline Nurses (per 100,000 population) & 651.3 & 6132 & $486.4^{4}$ & 454.9 & 892 & 696.9 \\
\hline Outpatient contacts per person per year & 7.2 & 7.1 & 7.4 & 5.6 & 9.5 & 6.9 \\
\hline Outpatient FD contacts per person per year ${ }^{t}$ & 0 & 3.1 & 0 & 3.0 & 0 & 32 \\
\hline Average length of stay (days) in all hospitals & 17.1 & 7.8 & 17.4 & 8.5 & 17.6 & 8.3 \\
\hline Acute care hospital discharges (per 100 population) & 17.1 & 15.9 & $20.1^{*}$ & 16.3 & $17.8^{2}$ & 203 \\
\hline $\begin{array}{l}\text { This number refers to } 1999 \text {. } \\
\text { b This number refers to } 2008 \text {. } \\
\text { c This number refers to } 1992 \\
\text { a This number refers to } 1996 . \\
\text { "This number refers to } 1998 \text {. }\end{array}$ & & & & & & \\
\hline
\end{tabular}


Põlluste, K., Kasiulevicius, V., Veide, S., Kringos, D.S., Boerma, W., Lember, M. Primary care in Baltic countries: a comparison of progress and present systems. Health Policy: 2013, 109(2) $122-130$

Table 2

Key characteristics of primary care reforms in Estonia, Latvia and Lithuania.

\begin{tabular}{|c|c|c|c|}
\hline Characteristics of reform & Estonia & Latvia & Lithuania \\
\hline $\begin{array}{l}\text { 1. Definition of } \\
\text { priorities/objectives }\end{array}$ & $\begin{array}{l}\text { Objectives formulated in } 1997 \text { : } \\
\text { - to create a list system so that the } \\
\text { population could register with a } \\
\text { primary care doctor; } \\
\text { - to introduce a partial } \\
\text { gate-keeping system; } \\
\text { - to introduce a combined } \\
\text { payment system for family doctors } \\
\text { (FDs); and } \\
\text { - to give FDs the status of } \\
\text { independent contractors. }\end{array}$ & $\begin{array}{l}\text { Objectives formulated in } 1995 \text { : } \\
\text { - to give the FDs the status of } \\
\text { independent contractors. } \\
\text { Objectives formulated in } 1998 \text { : } \\
\text { - to create a list system so that the } \\
\text { population could register with a } \\
\text { primary care doctor. } \\
\text { Objectives formulated in } 1999 \text { : } \\
\text { - to introduce a combined } \\
\text { payment system for the family } \\
\text { doctors (PDs); and } \\
\text { - to introduce a partial } \\
\text { gate-keeping system. }\end{array}$ & $\begin{array}{l}\text { Objectives formulated in } 1997 \text { : } \\
\text { - to create a list system so that the } \\
\text { population could register with a } \\
\text { primary care doctor; and } \\
\text { - to introduce a partial } \\
\text { gate-keeping system. } \\
\text { Objectives formulated in } 1999 \text { : } \\
\text { - to introduce a combined payment } \\
\text { system for the family doctors (FDs). }\end{array}$ \\
\hline $\begin{array}{l}\text { 2. Refining policies } \\
\text { - Legal support to reform } \\
\text { - Financing } \\
\text { - Staff developenent }\end{array}$ & $\begin{array}{l}\text { The ministerial regulations of } 1997 \\
\text { established: } \\
\text { - legal status of FDs; } \\
\text { - financing principles; and } \\
\text { - the package of services provided } \\
\text { by the FDs } \\
\text { The training of FDs: } \\
\text { - re-training of practicing doctors } \\
\text { since } 1991 \text {; and } \\
\text { - residency training in family } \\
\text { medicine since } 1993\end{array}$ & $\begin{array}{l}\text { The ministerial regulations of } 1999 \\
\text { established: } \\
\text { - legal status of FDs; } \\
\text { - financing principles; and } \\
\text { - the package of services provided } \\
\text { by the FDs } \\
\text { The training of FDs: } \\
\text { - re-training of practicing doctors } \\
\text { since 1992; and } \\
\text { - residency training in family } \\
\text { medicine since } 1993\end{array}$ & $\begin{array}{l}\text { The ministerial regulations of } 1999 \\
\text { established: } \\
\text { - legal status of FDs; } \\
\text { - financing principles; and } \\
\text { - the package of services provided } \\
\text { by the FDs } \\
\text { The training of FDs: } \\
\text { - re-training of practicing doctors } \\
\text { since } 1992 \text {; and } \\
\text { - residency training in family } \\
\text { medicine since } 1993\end{array}$ \\
\hline $\begin{array}{l}\text { 3. Reforming institutions } \\
\text { - Institution of FD } \\
\text { - Gate-keeping function of FDs }\end{array}$ & $\begin{array}{l}\text { Institution of FDs: } \\
\text { - independent contractor with } \\
\text { health insurance fund since } 1998 \\
\text { Gate-keeping function of FD: } \\
\text { - partial gate-keeping since } 1998\end{array}$ & $\begin{array}{l}\text { Institution of FD: } \\
\text { - independent contractor with } \\
\text { health insurance fund since } 1995 \text {; } \\
\text { - private practitioner since } 1995 \\
\text { Gate-keeping function of FD: } \\
\text { - partial gate-keeping since } 1999\end{array}$ & $\begin{array}{l}\text { Institution of FD: } \\
\text { - private practitioner since } 1995 \\
\text { Gate-keeping function of } \mathrm{FD} \text { : } \\
\text { - partial gate-keeping since } 1997\end{array}$ \\
\hline
\end{tabular}


Põlluste, K., Kasiulevicius, V., Veide, S., Kringos, D.S., Boerma, W., Lember, M. Primary care in Baltic countries: a comparison of progress and present systems. Health Policy: 2013, 109(2) $122-130$

Table 3

Definition of indicators used for evaluation of the structure and process of $\mathrm{PC}$

\begin{tabular}{|c|c|}
\hline Indicator title & Description \\
\hline \multicolumn{2}{|l|}{ Structure } \\
\hline \multicolumn{2}{|l|}{ Governance } \\
\hline Primary care goals & Formulation of primary care goals \\
\hline Policy on equality in access & Policy on the distribution of human resources \\
\hline (De)centralisation of PC & - PC unit within the Ministry of Health \\
\hline \multirow{2}{*}{ management and service developenent } & - PC policy development at the regional or local level \\
\hline & $\begin{array}{l}\text { - Stakeholder involvement in PC policy development } \\
\text { - (De)centralisation of PC service delivery }\end{array}$ \\
\hline \multirow{4}{*}{$\begin{array}{l}\text { R quality management } \\
\text { infrastructure }\end{array}$} & - Coordination of quality management \\
\hline & - Certification of providers \\
\hline & - Licensing of facilities \\
\hline & - Development of clinical guidelines \\
\hline Patient advocacy & Patient rights \\
\hline Multidisciplinary collaboration & - Multidisciplinary collaboration (governmental policy on cooperation or integration of PC services \\
\hline \multicolumn{2}{|l|}{ Econoenic conditions } \\
\hline Primary care expenditure & - Total expenditure on PC as $\%$ of total expenditure on health \\
\hline Family doctor coverage & - $\mathcal{Z}$ of the population covered or insured for costs of $\mathrm{FD}$ services (office and at home) \\
\hline Availability of farnily doctors & - Number of FDs per 100,000 population \\
\hline \multirow[t]{4}{*}{ Employment status of family doctors } & - Salaried with national, regional or local authorities \\
\hline & - Salaried with other physicians \\
\hline & - Self-employed with contract to health insurance fund (HIF) or health authority (HA) \\
\hline & - Self-employed without contract (paid by patients out-of-pocket) \\
\hline \multicolumn{2}{|l|}{ Remuneration options } \\
\hline \multirow[t]{2}{*}{ For salaried family doctors } & - Flat salary \\
\hline & - Salary related to the number of patients and/or performance indicators \\
\hline \multirow[t]{3}{*}{ For self-employed farnily doctors } & - Capitation \\
\hline & - Fee-for-service \\
\hline & - Mix of capitation and fee-for-services and/or other components \\
\hline \multicolumn{2}{|l|}{ Process } \\
\hline \multicolumn{2}{|l|}{ Access to primary care services } \\
\hline National availability of PC services & - Total number of FDs per 100,000 population \\
\hline Opening hours & - Minimum nurmber of working hours or days \\
\hline Hoene visits & - Average number of home visits per week per FD \\
\hline After-hours primary care & - Provision of after-hours PC \\
\hline \multicolumn{2}{|l|}{ Affordability of PC services } \\
\hline \multirow[t]{3}{*}{ Cost sharing for family doctor's care } & - Payment for the visit to the PD \\
\hline & - Payment for the medicines prescribed by the FD \\
\hline & $\begin{array}{l}\text { - Payment for the visit to a specialist prescribed by the FD } \\
\text { - Payment for the FD visit to the patient's home }\end{array}$ \\
\hline Patient dissatisfaction with PC prices & - Percentage of patients that rate FD care as not very or not at all affordable \\
\hline \multicolumn{2}{|l|}{ Acceptability of PC services } \\
\hline Patient satisfaction with access to PC & Percentage of patients that find it easy to reach and gain access to FDs \\
\hline \multicolumn{2}{|l|}{ Continuity of care } \\
\hline Patient list system & - Presence of patient list system \\
\hline Physician choice & - Possibility for patients to choose the FD with whom they want to register \\
\hline
\end{tabular}


Põlluste, K., Kasiulevicius, V., Veide, S., Kringos, D.S., Boerma, W., Lember, M. Primary care in Baltic countries: a comparison of progress and present systems. Health Policy: 2013, 109(2) $122-130$

Table 4

Governance of PC in Estonia, Latvia and Lithuamia.

\begin{tabular}{|c|c|c|c|}
\hline & Estonia & latvia & Lithuania \\
\hline Vision and goals for $\mathrm{PC}$ & $x$ & $\times$ & 0 \\
\hline Policy on equality in access & $x$ & $\times$ & 0 \\
\hline Special division of PC within the ministry & 0 & $x^{2}$ & $\times$ \\
\hline $\begin{array}{l}\text { Decentralisation of responsibilities (eg, setting priorities, } \\
\text { service provision) for } P C \text { at the regional/local level }\end{array}$ & 0 & 0 & $\mathbf{x}$ \\
\hline Decentralisation of PC service delivery & 0 & 0 & $\times$ \\
\hline Stakeholder involvement in PC policy development & $x$ & $\times$ & $\times$ \\
\hline \multicolumn{4}{|l|}{ Quality management } \\
\hline Formal requirements for FDs & $x$ & $\times$ & $\times$ \\
\hline Recertification of FDs & $x^{b}$ & $x^{2}$ & $x^{e}$ \\
\hline Licensing of facilities & $x$ & $\times$ & $\mathbf{x}$ \\
\hline Evidence-based clinical guidelines produced for FDs & $x$ & $\times$ & $\times$ \\
\hline Patient rights defined by legislative acts & $x$ & $\times$ & $x$ \\
\hline $\begin{array}{l}\text { Policy on multidisciplinary collaboration (governmental } \\
\text { policy on cooperation or integration of PC services laid } \\
\text { down in a law or policy paper) }\end{array}$ & $x$ & $\times$ & $\times$ \\
\hline
\end{tabular}

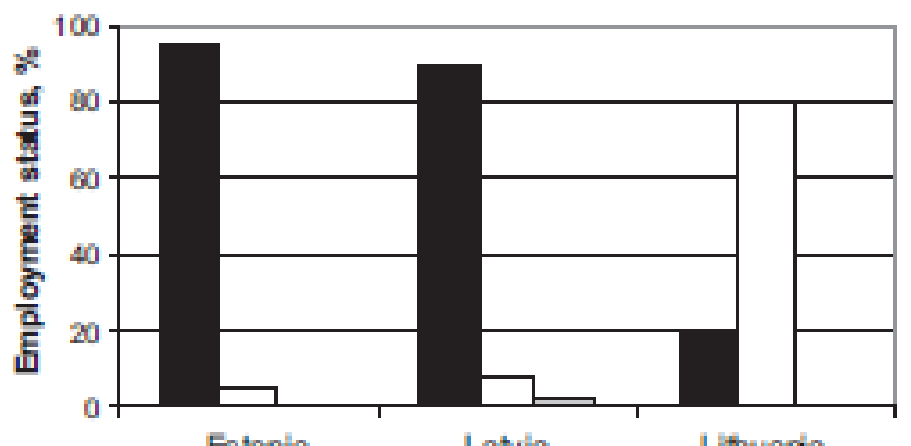

Estonla Latvia Lithuaria

- Sof -amployod with contract to had th inaunanos fund

QSaluriod with hadth authoritos or by oher physicians

口Sof-employod without contract

Fig. 1. Employment status of family doctors in Baltic countries.

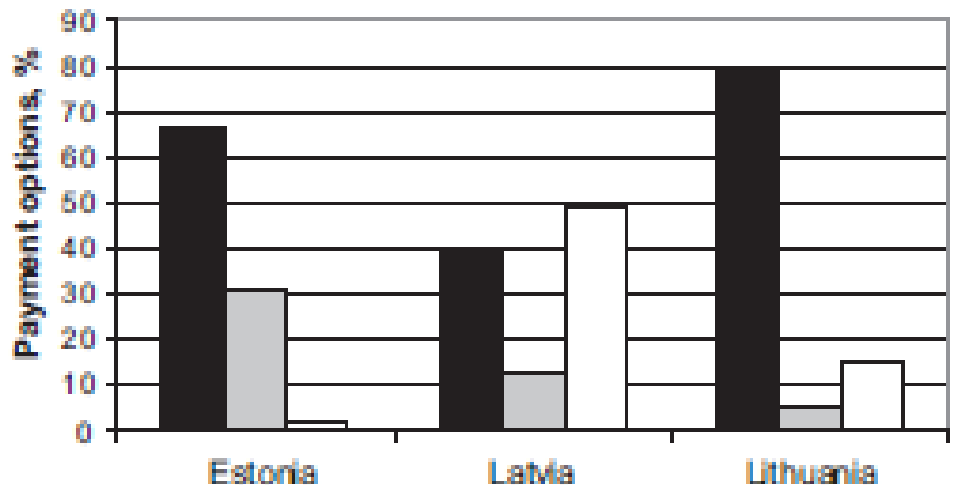

- Capt afion $\square$ Other fred compononts $\square$ Addifional components

Fig. 2. Structure of payment methods for family doctors in Baltic countries. 
Põlluste, K., Kasiulevicius, V., Veide, S., Kringos, D.S., Boerma, W., Lember, M. Primary care in Baltic countries: a comparison of progress and present systems. Health Policy: 2013, 109(2) 122-130

Table 5

Access, costs, and continuity of PC services in Estonia, Latvia, and Lithuania.

\begin{tabular}{|c|c|c|c|}
\hline & Estonia & Latvia & Lithuania \\
\hline \multicolumn{4}{|l|}{ Access to PC services } \\
\hline Total number of FDs per 100,000 population in 2008 & 62.4 & 58.4 & 68.1 \\
\hline Obligatory minimum number of opening hours & $\begin{array}{l}\text { 8h per working day } \\
\text { (Monday-Friday) }\end{array}$ & $40 \mathrm{~h}$ per week & $6 \mathrm{~h}$ per day \\
\hline Average number of home visits per week per FD & $22 \pi$ & $3.6^{b}$ & $10.0^{2}$ \\
\hline Provision of after-hours PC & Hospital/ambulance & $\begin{array}{l}\text { Hospital/health care } \\
\text { centre }\end{array}$ & Hospital \\
\hline \multicolumn{4}{|l|}{ Cost sharing for $\mathrm{PC}$ services } \\
\hline Payment for the visit to the FD & No & Yes & No \\
\hline Payment for the medicines prescribed by the FD & Yes & Yes & Yes \\
\hline Payment for the visit to a specialist prescribed by the FD & Yes & Yes & No \\
\hline Payment for the FD visit to the patient's home & Yes & Yes & No \\
\hline \multicolumn{4}{|l|}{ Continuity of care } \\
\hline Presence of patient list system & Yes & Yes & Yes \\
\hline Possibility for patients to choose the FD with whom they want to register & Yes & Yes & Yes \\
\hline
\end{tabular}

This number refers to 2008.

b This number refers to 2009

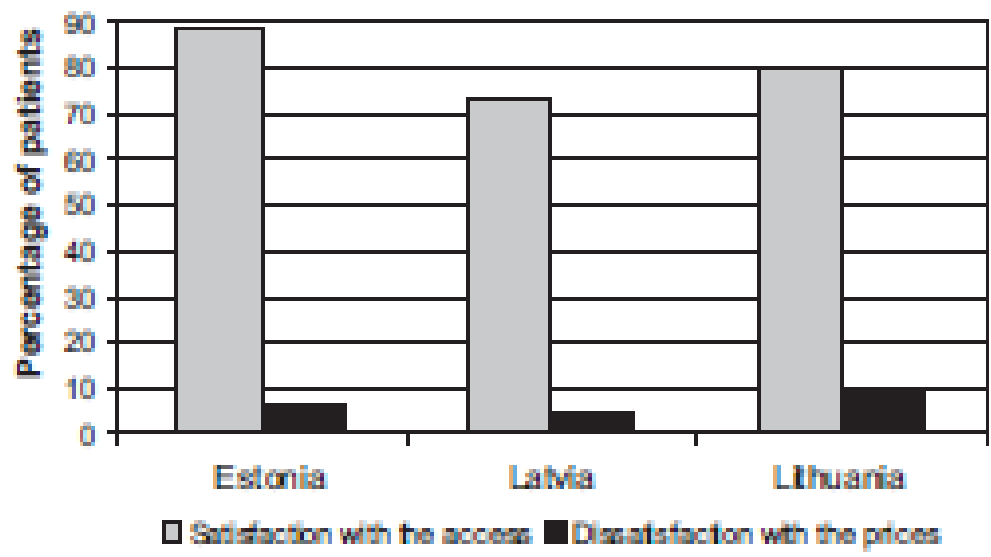

Fig. 3. Patient satisfaction with access to $\mathrm{PC}$ services and dissatisfaction with PC prices in Estonia, Latvia and Lithuania in 2007. 